\title{
TITLE:
}

\section{Influence of the sensory retina on healing of the rabbit retinal pigment epithelium(Abstract_要旨 )}

$\operatorname{AUTHOR}(\mathrm{S})$ :

Ozaki, Shiro

\section{CITATION:}

Ozaki, Shiro. Influence of the sensory retina on healing of the rabbit retinal pigment epithelium. 京都大学, 1997, 博士(医学)

ISSUE DATE:

1997-03-24

URL:

http://hdl.handle.net/2433/202179

RIGHT: 


\begin{tabular}{|c|c|}
\hline 氏 & $\begin{array}{llll}\text { 捤 } & \text { ざき } & \text { し } & \text { ろう } \\
\text { 志 } & \text { 郎 }\end{array}$ \\
\hline 学位 (専攻分野) & 博 士（医 学） \\
\hline 学 位 記 番 号 & 医 博 第 1862 号 \\
\hline 学位授与の日付 & 平成 9 年 3 月 24 日 \\
\hline 学位授与の要件 & 学位規則第 4 条第 1 項該 当 \\
\hline 研究科・専攻 & 医学研究科外科系専攻 \\
\hline 学位論文題目 & $\begin{array}{l}\text { Influence of the sensory retina on healing of the rabbit retinal } \\
\text { pigment epithelium }\end{array}$ \\
\hline
\end{tabular}

（家鬼網膜色素上皮修復に扔ける感覚網膜の影響）

論文調査委員 教授井出千束 教 授川口三郎教授本田孔士

\section{論 文 内容 の 要 旨}

視力予後の極めて不良な疾患のひとつ加龄黄斑変性は, 欧米をはじめ本邦においても増加しており, 哚 刻な問題となっている。この疾患に対し最近では, 網膜下新生血管膜除去, 㿍痕組織除去といった手術療 法が試みられているが, その成績は芳しくない。その主原因のひとつは, 異常組織除去の際に, 不可避に 黄斑部の網膜色素上皮（RPE）に障害を与えてしまう，またはその欠損を生じてしまうことにあるとさ れるが，これらRPE 障害・欠損に対する修復に着目した研究は皆無である。そこで，家兔眼を用いて $\mathrm{RPE}$ 擦過・障害モデルを作成し, 網膜の有無によりその修復過程が異なるか, RPE 細胞再生・分化に与 える影響はどうかを形態学的に検討した。本研究の目的は, 残存 RPE の再生・修復という，生体本来の 機能に着目し，そのメカニズムを明らかにし，加齢黄斑変性をはじめとする各種疾患への治療の道を開か んとする事にある。

家兔眼 RPE 擦過・障害モデルは, 家兔網膜下に顕微鏡下にてガラスマイクロピペットを挿入, 人工的 網膜缡離を作成した後，網膜切開を施行し，その部よりシリコンブラシ插入にて， RPE 擦過を行うこと で作成した。 RPE 除去網膜を完全に切除した網膜の存在しない群（40眼）と, 網膜を保存した網膜の存 在する群 $(27$ 眼) の 2 群に分け, 両群とも, 経時的に眼底鏡検査, 光学顕微鏡, 走査・透過電子顕微鏡に て検査を施行し，検討した。

眼底鏡検查では，両群とも術後 5 日まで灰白色を呈した RPE 擦過部は，術後14日までには周辺部より 徐々に色素増加が認められた。網膜の存在しない群では, 以後変化は少なかったが, 網膜のある群ではさ らに色素が増強した。形態学的には, 両群とも RPE 擦過・障害部は術後 5 日までに未分化 RPE 様細胞 により再被覆されていた。網膜のある群では, 残存した視細胞内節・外節の一部と接触していたが, 接着 構造は観察されなかった。術後14日にはRPEの再構築は完成した。この時網膜のない群では, 再生した 色素をもつ RPE 細胞は重層化しており, 環状・葉状構造を呈するものが多く認められ, これ以後著明な 変化が認められなかったのに対し, 網膜のある群では, 多くの場合 RPE 本来の一層の単層上皮を形成し, 
色素顆粒も細胞頂部に集積しだし，長い微絨毛を持つなどの分化傾向を示していた。これら再生 RPE と 感覚網膜との間には接着を認め, 術後 1 ケ月以降では, ほぼ正常に近い RPE-感覚網膜接合体を形成し, RPE 細胞内に新たに貪食したと考えられる phagosomeが存在していた。この状態は, 術後 4 ケ月におい ても観察され，再生 RPE が本来の RPEのもつ種々の機能を維持・発揮していることを示唆するものと 考えられた。

本研究により, 家兔 RPE 障害・欠損部は, 網膜の有無にかかわらず術後早期に再被覆され, 術後 2 週 間では再生 RPEにより再構築されることが明らかとなった。また，再被覆後の RPE 分化は感覚網膜と の接触・接着により影響を受けていることが示唆された。今回の実験モデルを利用することにより，更な る RPEの再生・分化のメカニズムの解明が期待でき, さらには今後ますます増加が見达まれる加齢黄斑 変性をはじめとする各種疾患の治療への道を開く第一歩として意義があると考える。

\section{論文審査の結果の要旨}

本邦においても急増している加齢黄斑変性等の黄斑部脈絡膜新生血管病変に対し, 手術による病巣直接 除去が試みられるようになった。しかし，その理論的裏付けとなる術後の網膜色素上皮 (RPE), 感覚網 膜の創傷治療に関する基礎的データは極めて少ない。その一因は，網膜創傷治療のモデルの作成が困難な ことにある。

本研究は, 家兔眼を用い, 顕微鏡下に他部位に障害を与えず RPE を擦過・障害モデルを作成, その修 復過程を RPE 除去部網膜切除群と網膜保存群の 2 群に分けて組織学的に比較・検討した。両群において, RPE 擦過部の再被覆は, RPE 擦過周囲の細胞移動により術後 5 日までに完了し, 術後 2 週間でシート状 の RPE が再構築されるが，感覚網膜除去群では，再生 RPE は重層化し，その分化形態が不均一である のに対し, 網膜の存在する群では, 再生 RPE は本来の単層構造を形成し, 術後 1 ケ月までに正常 RPE と同様の微絨毛・色素を持ち, 正常 RPE-視細胞環境が再構築された。

これらの結果より，家兔 RPE 障害・欠損部は，網膜の有無にかかわらず術後早期に再被覆されること， また再被覆後の RPE 分化は，感覚網膜との接触・接着により影響を受けていることが示唆された。

以上の研究は, RPE の創傷治潦の解明に貢献し, 本論文は博士（医学）の学位論文として価值あるも のと認める。

なお, 本学位授与申請者は, 平成 9 年 2 月 4 日実施の論文内容とそれに関する試問を受け, 合格と認め られたものである。 